\title{
An Overview About Fashion Retailing Sector: UK Versus Spain
}

\author{
Alejandro Mollá-Descals, University of Valencia, Spain \\ Carlota Lorenzo-Romero, University of Castilla-La Mancha, Spain \\ Juan-Antonio Mondéjar-Jiménez, University of Castilla-La Mancha, Spain \\ Teresa Fayos-Gardó, University of Valencia, Spain
}

\begin{abstract}
Within the international context, fashion retailers have suffered the most in the economic downturn in the last years. Nevertheless, the historically high-margin fashion sector's composite net profit margin was still the highest of all the product groups. Based on the importance of fashion retail sector for the international economy in general, this paper examines the international retailing situation showing sales data between most important retailers around the world in general and Europe in particular. Specifically, this paper offers an overview on fashion retailing sector in the international context in order to study the position of this sector in the international crisis context. Due to the importance of fashion sector for national economies, in this paper is carried out a comparison between two countries characterized for economic growing of this sector in general, and the women segment in particular: United Kingdom and Spain. As conclusion, some solutions are explained to face the current situation by the apparel retail management.
\end{abstract}

Keywords: Fashion Retail Sector; International Retail Database; International and European Retail Situation; Fashion Retail Solutions to Current Crisis Situation; Comparison United Kingdom-Spain

\section{INTRODUCTION}

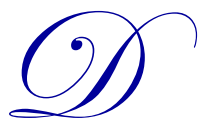

espite the current global economic downturn, the apparel retail industry continues to grow at a healthy rate and this, coupled with the absence of switching costs for consumers and great product differentiation, means that rivalry within the industry is no more than moderate. The United Kingdom (UK) apparel industry is of great importance to the economy in terms of trade, employment, investment and revenue for the country. This particular industry has short product life cycles, vast product differentiation and is characterized by great pace of demand change coupled with rather long and inflexible supply processes. Clothing is essential to consumers who are individuals. Where brand loyalty exists, it is more likely to be to the designer than the retailer, although this is usually towards the top end of the industry. There is a growing demand for discount apparel retail with stores such providing low cost prolific-output fashion. Fashion, by its very nature, is unpredictable. The products are determined by designers, sub-cultures and creative industries and are subject to sharp and unpredictable changes. Key suppliers in this industry are clothing manufacturers and wholesalers, with retailers able to source from both (Datamonitor, 2010).

Taking into account this retail framework, this paper examines the current retail situation of retail sector and, specifically, fashion retail sector in the international context focusing the attention in the specific case of UK. The study starts with an overview of international situation of retailing sector in general and clothing sector in particular, finishing with an overview about the women apparel sector in the international context. The fourth epigraph is focusing on fashion sector in UK, starting with the analysis of current economy situation of retail sector in this country, next with the study of fashion sector and, finally, with the specific case of women apparel in UK. Finally, based on analysis carried out, some conclusions and solutions are proposed and focused to fashion retailers. 
As Coca-Stefaniak et al. (2005) did for small shops independent retailer, we believe that a more fruitful approach than concentration on events in one country is comparative research in two or more countries. Our chosen comparator is Spain and we agree with the aforementioned authors that a useful background to retailing in the two countries can be found in Flavián et al. (2002) because they stressed that market innovations generally arrived later in Spain and that the Spanish market is more locally oriented (Coca-Stefaniak et al., 2005). Topics such as retail strategy have attracted much more academic interest in Britain than in Spain (Coca-Stefaniak et al., 2005); and although it is very difficult to make reliable comparisons because of the existence of structural differences both are characterized by the economic growing of this sector in general, and the women segment in particular. Nevertheless, we consider that the comparison of the characteristics of different countries sector will help to better understanding about convergences and divergences between countries on retailing sector.

\section{RETAILING, SITUATION AND PROSPECTS FROM ACADEMIC LITERATURE REVIEW}

Retailing is an ancient business, but retailing as an academic area of study has a less extensive history (Evans, 2011). Nevertheless, from the 1980s on there has been an expanding research interest in retailer internationalization (Dawson et al., 2008), and since the 1990s retail internationalization has received a significant amount of not only academic attention but also debate (Myers and Alexander, 2007). Nowadays, the area is rich in articles that address the subject of international retailing (Alexander and Doherty, 2010).

It is widely accepted that modern retailing is the accumulation of incremental steps over time. The state of retailing depends not only on the cyclical nature of the overall economy in a country or region, but also on specific factors endemic to retailing; and the theories of the retail life cycle, the wheel of retailing, and scrambled merchandising/retail accordion remain as valid and useful today as in the past (Evans, 2011). Nevertheless, this author considers that the aim of retailers has remained relatively steady over time: attract shoppers through distinctive offerings, grow the business, control costs, be profitable, adapt as necessary, and survive.

One of the most remarkable trends in the evolution of retailing is the increased industry concentration and business size. Large retailers in search of sustained growth increasingly decide to expand abroad, responding to and also contributing to the globalization process. Growing levels of retail internationalization are in part an outcome of the growing size and sophistication of retail businesses, but also a response to changing consumer demands and behaviours (Myers and Alexander, 2007). Today, operating internationally is commonly accepted as an option for growth, but also as a necessity in a scenario in which domestic European Unión most developed mature markets shows increasing levels of competition and commercial saturation (Lopez and Fan, 2009; Mollá-Descals et al., 2011). This increases the number of companies internationalizing their activities, no longer limited to big retailers.

As anticipation and adaptation are essential, retailers must consider at least three trends: First, as internet in the shopping experience continues expanding, customer expectations on it will also rise (Evans, 2011), and online shopping provides the opportunity to extend markets and attract new ones, and may provide retailers with unique opportunities for brand building (Kaufman-Sc and Forsythe, 2009), but without forgotten social media (Evans, 2011). Second, in regarding brands, a mixed brand strategies will dominate (Evans, 2011) and today consumers in global markets choose between local, national, and global brands. And third, Kaufman-Sc and Forsythe (2009) consider that new relationships among consumers, retailers, and their partners are emerging, and global markets and innovative forms of multichannel retailing demand a fresh look at the dynamics of today's retailing environment.

Regardless of size, line of business, or country of origin Evans (2011) proposes to retailers some orientations for the future: the retailer's focus must always be on consumers and how to best satisfy them, and the firm needs to be distinctive in at least one aspect of its strategy so as even a small firm could be a star retailer by serving an unfulfilled consumer need.

\section{THE CLOTHING RETAILERS IN THE INTERNATIONAL CONTEXT}

The fashion apparel industry has significantly evolved, particularly over the last 20 years (Bhardwaj and Fairhusrst, 2010). The demand side is characterized by the complexity of fashion consumption (Christopher et al., 2004), with diversity of consumers' requirements in terms of price, quality and innovativeness. Consumers have 
become more demanding, seeking greater variety and up-to-date styles at increasingly competitive prices (Fernie $e t$ al., 2009).

The changing dynamics of the fashion industry over this period, such as the fading of mass production, increase in number of fashion seasons, and modified structural characteristics in the supply chain (Doyle et al., 2006; Fernie et al., 2009; Bhardwaj and Fairhusrst, 2010) have forced retailers to desire low cost and flexibility in design, quality, delivery and speed to market (Doyle et al., 2006). Nevertheless, there exist also high-cost supply markets like Italy and Spain that have a significant number of manufacturing suppliers (Fernie et al., 2009).

Fashion retailing is therefore a complex industry (Mollá-Descals et al., 2011), that also includes several types of companies in terms of product commercialized, and brand strategy (chain retailers, designer retailers, and multi-brand retailers). Moreover, there are as well different supply channels or global sourcing strategies (Fernie $e t$ al., 2009; Mihm, 2010): Full vertical integration, house branding, and fully outsourced method.

Despite sector complexity, fashion retailers have been recognized among the most important international companies (Mollá-Descals et al., 2011), especially with the emergence of fashion retailer super-brands such as The Gap, Benetton and Gucci (Moore and Burt, 2007). Indeed, the international expansion of fashion retailers in Europe far outweighs the foreign activities of retailers commercializing other products (Doherty, 2000).

According to Mintel (2009), in Europe clothing is a highly competitive sector, with specialist players facing competition mainly from hypermarkets, department stores and online players; The overall economic outlook has worsened, which will make things difficult for clothing players, and as competitive pressure will grow consolidation is likely to accelerate. Fashionability has been a strong lure in the sector with the top end and lower-priced players performing strongly, and the development of fast fashion has met with an enthusiastic response; Fast fashion has also proved transferable across borders, underlined by the strong performance of Sweden's H\&M and Spain's Grupo Inditex in recent years. Primark, a UK business owned by ABF of Ireland, is expanding in Europe. Finally, the middle mass-market has struggled with consumers polarizing to lower-cost fashion or the higher end players.

\section{FASHION SECTOR IN UNITED KINGDOM AND SPAIN}

Fashion retailing in the UK is receiving increasing academic attention (Doherty 2000), and research has focused on branding (Birtwistle and Freathy, 1998), customer decision making (Birtwistle and Freathy, 1998), and so on. Recently, fast fashion issues (Bhardwaj et al., 2010), have also attracted interest because fast fashion will have a direct effect on the way consumers purchase and react to trends (Bhardwaj and Fairhusrst, 2010). However, compared with the huge retail internationalization literature, limited research attention has been paid to fashion retailers internationalization (Fernie et al., 1998; Burt et al., 2002). As emphasised by Fernie et al. (1998), this research neglect is somewhat anomalous, not only because fashion retailers are among the most successful of international retailers (Doherty, 2000), but also because in the UK (CIG, 1996), in terms of the number of retail firms operating in overseas markets, the fashion sector was the most internationalised (Doherty, 2000).

Fernie et al. (1998) agree with Dawson (1994) on the reasons why fashion retailers are more likely to be successful internationally compared to other retailing sectors: small format requiring limited capital and management set up costs; ease of entry and exit compared to manufacturing; single brand internationalisation format enables; more suited to franchising; and economies of replication. On the other hand, Doherty (2000) conclusions on entry mode strategy in international fashion retailing are that entry mode strategy emerges over time as a result of a combination of historical, experiential, financial, opportunistic, strategic and company-specific factors; and in the case of UK fashion retailers, franchising has emerged as the major entry mode and looks like continuing to do so into the future, contrary to Burt (1993) opinion that as retailers become experienced will move to higher risk modes, such as acquisition or organic growth.

The Spanish fashion retail industry also reflects the aforementioned trend (Mollá-Descals et al., 2011) that expansion of fashion retailers in Europe far outweighs the foreign activities of retailers commercializing other products (Doherty, 2000). In particular, the Spanish fashion retail chain Zara is the most international Spanish brand and one of the most successful fashion retailers, representing an example of global expansion (Lopez and Fan, 
2009). Other Spanish fashion store chains such as Mango and Adolfo Domínguez have a wide international presence, while other retailers operate exclusively in their country of origin (Baena, 2008).

Spanish fashion retailers share the main characteristics and challenges of textile and clothing companies in other European countries such as Italy or Great Britain (Lopez and Fan, 2009). These trends are highly concentrated distribution channels, increasing internationalization, emergence of international competitors, outsourcing and reevaluation of the business models to adapt to customers' changing tastes (Lopez and Fan, 2009).

As in other European countries (Mollá-Descals et al., 2011) it is found also in Spain fashion retailing the aforementioned complexity in terms of product commercialized and brand strategy, such as chain retailers (e.g. Zara, Mango), designer retailers (e.g. Adolfo Domínguez, Custo, V\&L) and multi-brand retailers (Area Interior). The same researchers after studying the Spanish fashion retail companies suggested to retailers seeking internationalization that internationalization should be a carefully planned long-term strategy, and the process of internationalization can bring about not only economies of scales in sourcing and logistics, but also economies of scope in managements systems and technologies.

\subsection{Market analysis: United Kingdom and Spain}

According to Datamonitor (2010), the apparel retail industry in the UK has grown moderately in value in recent years and the growth rate is forecast to fluctuate in the years up to 2014. The distribution of fashion sales in Spain by type of customer, regardless of who acquire, gives priority to selling women's clothing (37.5\% of total turnover in Spain), followed by men's clothing (32.3\%), home textiles (20.9\%) and children's clothing (9.3\%). Expense structure remains unchanged over the past five years.

The UK apparel retail industry had total revenue of $\$ 63,108.3$ million in 2009 , representing a compound annual growth rate (CAGR) of 1.9\% for the period spanning 2005-2009 (Euromonitor, 2010a). According to KeyNote (2010), the UK apparel market was worth an estimated $£ 46.05$ billion in 2009 , accounting for $5.3 \%$ of total consumer spending. In 1960, these products, accounted for $10 \%$ of the household budget, so they have lost relative importance in the consumer economy. The main reason for the apparel market's failure to grow rapidly is price deflation. Between 2005 and 2009, the market grew by $6 \%$ at current prices but much higher volumes of apparel were bought at lower prices. The women's outerwear actually declined slightly in value, because average prices were 22\% lower in 2009 than they were in 2005 and this occurred despite the dynamism of 'fast fashion'. Prices for some clothing items have, in fact, declined for a much longer period even relative to late 1980s prices. This is attributable to two long-term factors: cheaper imports and retail competition. In the 1990s, in order to stay in competition, some retailers shifted sourcing of merchandise to the Far East for a low cost advantage. Therefore supply chains became more complex forcing retailers to, not only introduce practices such as just-in-time, computer integrated manufacturing, and total quality management in manufacturing, but also shortening supply lines and speeding response in the market (Bruce/Daly/Towers 2004). Retail competition, the other factor in restraining prices, has featured the broadening out of retail sources for apparel, to take in new waves of competitors such as sports shops and deep discounters in the 1990s and the Internet and grocery superstores in the 2000s. Key Note's consumer research for this report found that people spread their shopping for apparel across a wide variety of generalist outlets - chain stores (e.g. Primark), grocery superstores (e.g. ASDA), sports shops (e.g. Sports World) and department stores (e.g. Debenhams) - in addition to fashion chains, shoe shops and mail-order catalogues, the traditional outlets. The decline of domestic production and the ultra-competitive retail environment means that retailers now dominate the apparel market.

Since its beginning, the fashion apparel industry in UK has been characterized by high levels of dominance by large retailers with inflexible supply chains (Hines and Bruce, 2001). As a result (Bhardwaj and Fairhusrst, 2010) retailers in the UK started providing increased variety and fashionability to their customers, keeping in mind the low cost of the merchandise. These large retailers, also added more phases to the existing seasons, resulting in providing high and fast fashion at a low price. This is the reason (Bhardwaj and Fairhusrst, 2010) why the UK fashion industry has been widely acknowledged to have initiated the fast fashion strategy in the fashion industry (Barnes and LeaGreenwood, 2006). 
In Spain, distribution patterns in the clothing market remained virtually unchanged in 2008 from those of the previous year. Specialist stores remained at the top of the ranking with a market share of around 55\%, because consumers are more confident in this type of store and suppose that the quality offered will be higher. Nevertheless, they have gradually lost share to grocery and mixed retailers, which offer lower prices. Home shopping is only available in some parts of the country, but the increase in Internet sales is notable in nearly all subsectors.

One of the main effects of the economic crisis has been consumers' opting for lower-priced products. Many of the brands that were previously sold at a mid-market price point have opted to reduce their prices, and in many cases the quality as well. The decline in the aggregate market volumes has been marked, but considerably less so than the fall in market value because of this shift towards cheaper and lower-quality brands, although there were no substantial changes in the high-end and luxury segments. The current economic crisis has led to an increase in the sales of clothing sold in super/hypermarkets, which is usually of poor quality and sold at very low prices. Spanish consumers are now reluctant to spend on Spanish fashion, although it is among the best in the world, because its prices are relatively high. The opening of new outlets in Spain was a boost for many companies that sold their stock through these stores. Sales through Internet stores also grew enormously during 2008.

According to ICEX (2008), the UK imports of clothing outside, both male and female, continue to increase year after year. The main supplier in the UK is China, which ranks first as a supplier in 9 of the 14 tariff items of clothing outerwear analyzed and $100 \%$ of tariff items of footwear.

In the Spanish fashion sector, exports have grown dramatically since 1993, but in 2009 both exports and imports experienced a decline despite the commitment to international business. Among the countries of exports destination (ICEX, 2010) are France, Portugal, Italy, Germany, and UK; and among the importers: China, Italy, France, Turkey, and Portugal.

\subsection{Analyzing a specific segment: Women fashion in UK and Spain}

Despite overall declines in the women's apparel segment, a group of shoppers say they will continue to spend in the category and will represent a disproportionate percentage of category sales, according to Kurt Salmon Associates' analysis of BIGResearch's most recent study of more than 8,000 shoppers' opinions. Kurt Salmon Associates (2009) research shows that women are more inclined to change their behaviors and in particular, they are more likely to become more practical and realistic in their purchases, focus on needs rather than wants and become more budget conscious. Women have also deferred more discretionary purchases than men, with the biggest discrepancies being in going out to eat and apparel purchases. Because 37\% of women continue to defer apparel purchases, women's apparel sales are likely to remain sluggish in the near future. However, a target group of "confident" women shoppers will maintain or increase their women's apparel spending. This target group is younger and more brand conscious, they prefer shopping at department stores and specialty stores for women's apparel, as opposed to discounters, and they are also more demanding shoppers, placing higher expectations across many nonprice aspects of retailers, like selection, quality and styles.

Because this target group's spending represents a considerable $57 \%$ of women's apparel sales, retailers and brands that target this group are more likely to be successful in the coming months.

In the European womenswear market value, UK accounts for $16.6 \%$ and Spain accounts for $6.2 \%$, Germany accounts for a further $20.2 \%$ of the European market. Womenswear is the largest segment of the apparel retail industry in the UK, accounting for $54.6 \%$ of the industry's total value.

Sales of womenswear proved the most lucrative for the UK apparel retail industry in 2009, with total revenues of $\$ 34,461.6$ million, equivalent to $54.6 \%$ of the market's overall value. In comparison, sales of menswear generated revenues of $\$ 20,282.1$ million in 2009 , equating to $32.1 \%$ of the industry's aggregate revenues. 


\section{CONCLUSIONS}

As a result of 20 years of sustained research on international retailing various conclusions may be drawn (Alexander and Doherty, 2010): International retailing is reasonably well understood; as an area of investigation in its own right, there is a body of work that describes and analyses the process; and as an important component of the service sector, retailing contributes a wider understanding of the broader internationalization process.

The global recession changed the behavior of consumers. They became more value conscious, more attracted to private labels and less likely to purchase large discretionary items. Yet the duration and depth of the recent downturn raises the possibility that these changes in consumer behavior will be sustained even after recovery takes place. This would apply principally to those markets in which consumer spending had been excessive during the pre-recession era and where spending was fueled by debt (eg. United States, UK, Spain). If this pattern holds, it will have important implications for retailers operating in large developed markets. First, they will have to offer consumers a favorable value proposition. A good value proposition will entail being clearly differentiated from competitors so that consumers sense a unique offering - perhaps through exclusive brands (Mihm, 2010) - and become less likely to compare prices. In addition, smart retailers will focus on brand management in order to convey their value proposition. They will also focus on improvements in customer experience as a differentiating factor. Second, retailers may find necessary to shift their resources toward the development of discount concepts, but the problem, of course, is that discount formats can cannibalize higher-priced formats; thus, this strategy could prove to be a zero-sum game. Finally, challenging conditions in markets like the United States and UK may compel retailers to invest in newer markets. Thus, the value orientation of rich country consumers could have the effect of accelerating retail globalization.

Euratex (2010) launched two enquiries to value the problems faced by textile and clothing companies that confirmed that companies were complaining about the growing restrictiveness in accessing credit for their daily business. Additionally, among the first measures identified by companies to invest to prepare the future they cited having invested strongly to enhance their marketing, innovation and design capacities together with further improvements in the quality of the products. In addition efforts towards a better integration with the retail/distribution and better training and skills of the workers were underlined.

According to Euromonitor (2010b), most retailers will continue to implement expansion programs in order to drive growth and in order to maintain interest from investors. However, only a few retailers are expected to succeed with their expansion plans, and saw a number of ambitious retailers find themselves in poor financial situations due to extensive expansion plans. The recession led to a number of retailers suffering from significant financial difficulties. Many retailers nevertheless continued to expand and consequently suffered decline in samestore sales or even overall sales in a weak consumer environment.

Leading retailers and emerging retailers in channels such as supermarkets and discounters are likely to continue with their expansion plans, with these set to accelerate at the end of the recession. However, their expansion is expected to be largely at the expense of smaller or struggling companies. The acquisition or disappearance of these smaller or poorly-performing chains will lead to a number of store closures in the long-term. UK high street retailing will thus be led by fewer brands. Many believe that this "decluttering" of the UK retail environment is a necessary process and, although it was triggered by the recession, would have eventually happened regardless of the state of the economy.

While strong UK retailers will continue to expand in the UK, many will see more dramatic growth in emerging countries such as the UAE, which saw dynamic retail growth towards the end of the review period. Many retailers already recognized the potential for growth in rapidly-emerging countries such as China. Marks \& Spencer opened its first Chinese store in October 2008. Successful retailers will also invest in renovating older stores in addition to their expansion plans, as consumers will continue to be attracted by new products and environments.

Therefore, as retailers focus on areas other than outlet expansion in the UK, retailing will struggle to achieve volume growth and outlet volume for store-based retailing will decline (Euromonitor, 2010b). 


\section{ACKNOWLEDGEMENT}

This study is framed within Research Project reference number ECO2009-08708 (Ministry of Science and Innovation, Government of Spain, 2010-2012).

\section{AUTHOR INFORMATION}

Alejandro Mollá-Descals, Ph.D. in Economics and Degree in Business Administration by University of Valencia. Professor in Marketing Department. Faculty of Economics, University of Valencia (Spain). Research Interest: Retailing, trade marketing, and international commerce. Phone +34 963828 312; Fax +34 963864 885; E-mail: Alejandro.Molla@uv.es

Carlota Lorenzo-Romero, Ph.D. in Economics and Degree in Business Administration by University of CastillaLa Mancha. Assistant Professor in Business Administration Department. Faculty of Economics and Business of Albacete, University of Castilla-La Mancha (Spain). Research Interest: Electronic commerce, social web, and retailing. Phone +34 902204 100; Fax +34 902204 130; E-mail: Carlota.Lorenzo@uclm.es

Juan-Antonio Mondéjar-Jiménez, Ph.D. in Economics and Degree in Business Administration by University of Castilla-La Mancha. Associate Professor in Business Administration Department. Faculty of Social Sciences of Cuenca. University of Castilla-La Mancha (Spain). Research Interest: Pricing, tourism, and retailing. Phone +34 902204 100; Fax +34 902204 130; E-mail: JuanAntonio.Mondejar@uclm.es (Corresponding author)

Teresa Fayos-Gardó, Ph.D. and Degree in Economics by University of Valencia. Assistant Professor in Marketing Department. Faculty of Economics, University of Valencia (Spain). Research Interest: Retailing, trade marketing and international commerce. Phone +34 961625 379; Fax +34 963864 885; E-mail: Teresa.Fayos@uv.es

\section{REFERENCES}

1. Alexander, N. and Doherty, A.M. (2010): “International retail research: Focus, methodology and conceptual development", International Journal of Retail and Distribution Management, Vol. 38 No. 11, pp. 928-942.

2. Baena, V. (2008): "La expansión internacional de la franquicia española: descripción del momento actual" [Internationalization expansión of Spanish franchising: Description of current moment], Proyecto Social:

Revista de relaciones laborales, Vol. 12 No. 12, pp. 41-64.

3. Barnes, L. and Lea-Greenwood, G. (2006): "Fast fashioning the supply chain: shaping the research agenda", Journal of Fashion Marketing and Management, Vol. 10 No. 3, pp. 259-271.

4. Bhardwaj, V. and Fairhurst, A. (2010): "Fast fashion: response to changes in the fashion industry", The International Review of Retail, Distribution and Consumer Research, Vol. 20 No. 1, pp. 165-173.

5. Birtwistle, G. and Freathey, P. (1998): "More than just a name above the shop: A comparison of the branding strategies of two UK fashion retailers", International Journal of Retail and Distribution Management, Vol. 26 No. 8, pp. 318-23.

6. Bruce, M., Daly, L., and Towers, N. (2004): "Lean or agile: A solution for supply chain management in the textiles and clothing industry?", International Journal of Operations \& Production Management, Vol. 24 No. 2, pp.151-170.

7. Burt, S.L., Mellahi, K., Jackson, T.P., and Sparks, L. (2002): "Retail internationalisation and retail failure: issues from the case of Marks and Spencer", International Review of Retail, Distribution \& Consumer Research, Vol. 12 No. 2, pp. 191-219.

8. Christopher, M., Lowson, R. and Peck, H. (2004): "Creating agile supply chains in the fashion industry", International Journal of Retail \& Distribution Management, Vol. 32 No. 8, pp. 367-76.

9. Coca-Stefaniak, A., Hallsworthb, A.G., Parkera, C., Bainbridgea, S., and Yuste, R. (2005): "Decline in the British small shop independent retail sector: Exploring European parallels", Journal of Retailing and Consumer Services, No. 12, pp. 357-371.

10. Corporate Intelligence Group (CIG) (1996): UK Retailers' Cross-border Activity, The Corporate Intelligence Group, London. 
11. Datamonitor (2010): “Apparel Retail in the United Kingdom”, Reference Code: 0183-2005.

12. Dawson, J. (1994): "The internationalisation of retailing", Journal of Marketing Management, Vol. 10, pp. 267-82.

13. Dawson, J., Findlay, A., and Sparks, L. (2008): The retailing reader. Abingdon, VA: Routledge.

14. Deloitte (2009): "Revisiting retail globalization", available at http://www.deloitte.com/assets/DcomUnitedStates/Local\%20Assets/Documents/us_retail_globalization.pdf

15. Doherty, A.M. (2000): "Factors Influencing International Retailers' Market Entry Mode Strategy: Qualitative Evidence from the UK Fashion Sector”, Journal of Marketing Management, Vol.16 No. 1, pp. 223-245.

16. Doyle, S.A., Moore, C.M., and Morgan, L. (2006): "Supplier management in fast moving fashion retailing”, Journal of Fashion Marketing and Management, Vol. 10 No. 3, pp. 272-81.

17. Euromonitor (2010a): "Clothing and Footwear Specialist Retailers - United Kingdom".

18. Euromonitor (2010b): "Retailing - United Kingdom. Euromonitor International: Country Market Insight".

19. Evans, J.R. (2011): "Retailing in perspective: The past is a prologue to the future", International Review of Retail, Distribution and Consumer Research, Vol. 21 No.1, pp. 1-31.

20. Fernie, J., Maniatakis, P.A, and A. Christopher C.M. (2009): "The role of international hubs in a fashion retailer's sourcing strategy", The International Review of Retail, Distribution and Consumer Research, Vol. 19 No. 4, pp. 421-436.

21. Fernie, J., Moore, C.M., and Lawrie, A. (1998): "A tale of two cities: an examination of fashion designer retailing within London and New York”, Journal of Product \& Brand Management, Vol. 7 No. 5, pp. 36778 .

22. Hines, T. and Bruce, M. (2001): Fashion Marketing Contemporary Issues. Butterworth and Heinemann. Oxford.

23. ICEX (2008): "El Mercado de la moda joven en Reino Unido" [The young fashion market in United Kingdom], available at www.icex.es

24. Kaufman-Scarborough, C., and Forsythe, S. (2009): "Current issues in retailing: Relationships and emerging opportunities. Introduction to the special issue from the American Collegiate Retailing Association 2005 and 2006 conferences", Journal of Business Research, Vol. 62 No. 5, pp. 517-520.

25. KeyNote (2010): "Clothing \& Footwear Industry, Market Report 2010", available at http://www.keynote.co.uk/market-intelligence/view/product/2401/clothing-\%26-footwearindustry/1/executive-summary?utm_source=kn.reports.related

26. Lopez, C. and Fan, Y. (2009): "Internationalisation of the Spanish Fashion Brand Zara", Journal of Fashion Marketing and Management, Vol. 13 No. 2, pp. 279-296.

27. Mihm, B. (2010): "Fast fashion in a flat world: Global sourcing strategies", The International Business \& Economics Research Journal, Vol. 9 No. 6, pp.55.

28. Mollá-Descals, A., Frasquet-Deltoro, M., and Ruiz-Molina, M.E. (2011): "Internationalization patterns in fashion retail distribution: implications for firm results", The Service Industries Journal, First published on: 24 February 2011.

29. Moore, C. and Burt, S. (2007): "Developing a research agenda for the internationalization of fashion retailing", Hines, T; Bruce, M. (Eds.), Fashion marketing: Contemporary issues, London: ButterworthHeinemann.

30. Myers, H. and Alexander, N. (2007): "The role of retail internationalization in the establishment of a European retail structure", International Journal of Retail and Distribution Management, Vol. 35 No. 1, pp. 6-19.

31. The European Apparel and Textile Confederation (2010): "Activities of the year 2009. Annual Report", available at http://euratex.eu/content/annual-report-euratex-2009 